\title{
The Empirical Study on Income Structure Changing to Farmers' Income Growth in Heilongjiang Province
}

\author{
Lou Sha ${ }^{1, a^{*}}$ \\ ${ }^{1}$ Harbin University of Commerce, Harbin China 150028 \\ a lousha1983@163.com
}

\begin{abstract}
Keywords: Grain production; Farmers' income; Income structure; Correlation analysis; Proportion
\end{abstract} of family operating income

\begin{abstract}
Heilongjiang, as a traditional agricultural province, the grain output accounts for one-tenth of the country and the grain production status is very important. Farmers' income structure in Heilongjiang has distinct characteristics, whether it has a certain impact on farmers' income growth or not, which is the core of this paper. Through the correlation analysis, we come to the conclusion that there is a significant relationship between the income growth and the structure of farmers in Heilongjiang. When the proportion of family operating income is increased, it is not conducive to the increase of farmers' income.
\end{abstract}

\section{Introduction}

From the past domestic development experience, diversified income is conducive to farmers' income growth [1]. Then, whether farmers' income growth in Heilongjiang is closely related to farmers' income structure or not, this paper introduces the correlation analysis on the specific impact of income proportion on farmers' income in Heilongjiang and explores the correlation between income structure and income increment [2-4].

\section{Model Selections}

In this paper, the simple correlation coefficient is Pearson's simple correlation coefficient. This part draws on Zhang Hongbing's analysis method (Zhang Hongbing et al., 2007). The concrete formula is as follows:

$$
r=\frac{\sum_{i=1}^{n}\left(x_{i}-\bar{x}\right)\left(y_{i}-\bar{y}\right)}{\sqrt{\sum_{i=1}^{n}\left(x_{i}-\bar{x}\right)^{2}\left(y_{i}-\bar{y}\right)^{2}}}
$$

Among them, $\mathrm{n}$ is the sample size, ${ }^{x_{i}}$ and ${ }^{y_{i}}$ are the two variable sample values, $\bar{x}_{\text {is }}$ the average of the variable $x, \bar{y}$ is the average of the variable $y$.

\section{Data Feature Analysis}

Using SPSS software to describe the characteristics of the selected data, the following table:

Table 1 Descriptive Statistics

\begin{tabular}{|c|c|c|c|c|c|}
\hline & $\mathrm{N}$ & Minimum & Maximum & Mean & Std. Deviation \\
\hline Farmers' income increment & 21 & -87.00 & 1380.00 & 387.2500 & 399.87365 \\
\hline Proportion of family operating income & 21 & 63.03 & 91.70 & 76.7545 & 9.76532 \\
\hline Proportion of wage income & 21 & 5.89 & 21.12 & 14.3440 & 4.93989 \\
\hline Proportion of property income & 21 & .38 & 7.18 & 4.0610 & 2.03229 \\
\hline Proportion of transfer income & 21 & 1.02 & 11.90 & 4.8390 & 3.85431 \\
\hline Valid N (listwise) & 21 & & \multicolumn{2}{|l}{} \\
\hline
\end{tabular}




\section{Correlation Results Analysis}

The following results are obtained by simple correlation analysis with SPSS software:

Table 2 Correlations

\begin{tabular}{|c|c|c|c|c|c|}
\hline & $\begin{array}{c}\text { Proportion of } \\
\text { family } \\
\text { operating } \\
\text { income }\end{array}$ & $\begin{array}{c}\text { Proportion } \\
\text { of wage } \\
\text { income }\end{array}$ & $\begin{array}{c}\text { Proportion of } \\
\text { property } \\
\text { income }\end{array}$ & $\begin{array}{c}\text { Proportion of } \\
\text { transfer } \\
\text { payment }\end{array}$ \\
\hline $\begin{array}{c}\text { Increment of per } \\
\text { capita farmers' } \\
\text { income in } \\
\text { Heilongjiang }\end{array}$ & $\begin{array}{c}\text { Pearson } \\
\text { Correlation }\end{array}$ & $-0.725(* *)$ & $0.583(*)$ & $0.668(* *)$ & $0.743(* *)$ \\
\hline $\begin{array}{c}\text { Sig. } \\
(2-\text { tailed }) \\
\mathrm{N}\end{array}$ & .000 & .001 & .006 & .000 \\
\hline
\end{tabular}

From the analysis, we know that the correlation coefficient between the proportion of family operating income and farmers' income increment in Heilongiiang is -0.725 . The proportion of wage income, property income and transfer payment has a positive impact on farmers' income in Heilongjiang and the correlation coefficients are $0.583,0.668$ and 0.743 . All the above results are tested by $\mathrm{t}$ test and the correlation is very significant.

In comparison, the negative correlation between family operating income and farmers' income increment in Heilongjiang is very obvious. That is to say, the growth on the proportion of family operating income is not conducive to the income growth. On the contrary, the growth on the proportion of wage income, property income and transfer payment income is conducive to the expansion of farmers' income.

To sum up, the proportion of farmers' family operating income in Heilongjiang is relatively high and it has negative impact on income increment, which is not conducive to farmers' income growth in Heilongjiang. On the contrary, the proportion of wage income, property income and transfer payment has a positive relationship with farmers' income increment. However, the proportion is too small, which is still not conducive to farmers' income growth in Heilongjiang.

\section{Conclusions}

(1) The proportion of family operating income and income increment is negatively correlated. According to the correlation analysis, the proportion of farmers' family operating income in Heilongjiang is reduced by one percentage point and farmers' income increment will be increased by 0.725 percentage points. The result is tested by $t$ test. According to the dual economic structure theory of the number of workers and peasants labor force conversion, we can conclude that the proportion of farmers' family operating income should show a reduction trend. Income growth is evident during the entire structure changing of farmers' income. This is consistent with the empirical analysis of the relationship between income structure changing and income growth in Heilongjiang [5].

(2) The proportion of wage income and income increment is positively correlated. According to the correlation analysis, the proportion of farmer's wage income in Heilongjiang is increased by 1 percentage point and farmer's income increment will be increased by 0.583 percentage points. The result is verified by $t$ test. Similarly, according to the dual economic structure theory of the number of workers and peasants labor force conversion, we can conclude that the proportion of farmers' wage income should show a growth trend and with the rising wage income, which is conducive to farmers' income growth [6]. The hypothesis is validated in the empirical analysis of the income structure changing and farmers' income growth in Heilongjiang.

(3) The proportion of property income is positively related to the income growth. According to the correlation analysis, the proportion of farmers' property income in Heilongjiang is increased by 
1 percentage point and farmer's income increment will be increased by 0.668 percentage points. The result is tested by $t$ test. According to the experience of developed countries and the theory of dual economic structure, farmers' property income will become the third source of income equal to family operating income and wage income in the future [7]. Through empirical analysis, it is concluded that the proportion of farmers' property income in Heilongjiang is positively correlated with farmers' income growth.

(4) The proportion of transfer income is positively related to the income growth. According to the correlation analysis, the proportion of farmers' income transfer in Heilongjiang is increased by 1 percentage point and farmers' income increment will be increased by 0.743 percentage points. The result is verified by $t$ test. According to the dual economic structure theory of the number of workers and peasants labor force conversion, such as triggering food crisis [8]. It can be concluded that with the transfer of labor force, the proportion of farmers' transfer income should have a growth trend.

On the whole, the income structure of farmers in Heilongiiang is closely related to the farmers' income growth. In other words, the diversified development is conducive to farmers' income growth in Heilongjiang [9]. On the contrary, it is not conducive to farmers' income growth. In order to fundamentally solve the problem of farmers' income structure in Heilongjiang, to reduce the proportion of family operating income appropriately, to promote the rapid growth of wage income, to secure the diversification of farmers' income will be a major theme in the future [10].

\section{Acknowledgments}

The paper is funded by the National Social Science Fund General Project "Research on Rural Financial Service Innovation and Risk Control in the Background of Agricultural Land Reform" (16BJL037).

\section{References}

[1] Xu Xiaohong China income gap between urban intergenerational transmission change trend: 2002-2012 [J] China Industrial Economy, 2015, (03): 5-17.

[2] Ding Zhiwei, Zhang Gaisu, Wang Fazeng. Spatio - temporal Differentiation of Multi - scale Urban and Rural Income in Central China [J]. Geography Research, 2015, (01): 131-148.

[3] Ann Tongliang, Qian Huixiong. Study on the Impact Mechanism of Chinese Residents' Income Gap on Enterprise Product Innovation [J]. Economic Research, 2014, (09): 62-76.

[4] Deng Mengzhi. The reform of the current grain subsidy policy and reform proposals [J]. Agricultural Economics, 2014, (09): 58-60.

[5] Li Dao. Grain subsidies to grain farmers to enhance the willingness to do? - From the perspective of farmers [J] Central University of Finance and Economics, 2014, (05): 86-94.

[6] Wan Haiyuan. The Impact of Household Discrimination on Urban-rural Income Gap [J]. Economic Research, 2013, (09): 43-55.

[7] Zhang Derong. The Mechanism of "Secondary Income Trap" and the Stages of China's Economic Growth [J]. Economic Research, 2013, (09): 17-29.

[8] Xu Jianwei, Ma Guangrong, Li shi. Personal Income Tax to Improve China's Income Distribution - Based on the Dynamic Evaluation of Microscopic Data from 1997 to 2011 [J]. Chinese Journal of Social Sciences, 2013, (06): 53-71 + 205.

[9] Wen Tao, Tian Jihua, Wang Xiaohua. Study on the Overall Influence of Farmers' Income Structure on Consumption Structure and Regional Difference [J]. China Soft Science, 2013, (03): 42-52.

[10] Zhang Dehua. Financial support, scale management and farmers' income in Heilongjiang Province[M].Beijing: China Fortune Press,2015. 